\title{
Diversity of Coastal Sand Dune (CSD) Vegetation along the Coast of Maharashtra, India
}

\author{
Ganesh P. Pawar and Ajit B. Telave \\ Post-Graduate Research Centre, Department of Botany \\ Tuljaram Chaturchand College of Arts, Science and Commerce, Baramati-413 102, India \\ E-mail: gpawar1947@gmail.com
}

\begin{abstract}
The sand dunes vegetation in coastal regions of Maharashtra is important ecosystems because of their small size, the different species found in habitat, and the beautiful landscapes they create. The current study investigated the vegetative status of sand dunes on Sindhudurg and Raigad district, west coast of Maharashtra. A survey of sand dune flora along coastal sand dune areas was done from October to December 2020 and 55 species belonging to 46 genera and 26 families are identified from study sites. The families like Fabaceae, Rubiaceae, Poaceae, Asteraceae, Lamiaceae and Malvaceae are dominant in study areas which show halophytic and xerophytic nature. The heavy pressure of tourism and development in coastal area shows negative effects on sand dune vegetation are seen during study.
\end{abstract}

Keywords: Ecosystems, Coastal sand dunes, Maharashtra, Halophyte, Diversity

Coastal zones are the most productive and invaluable areas of coastal water and adjacent land forms and are the places of high priority interest of people, commerce, military and variety of industries. Coastal sand dune (CSD) serves as an ecological niche between terrestrial and marine life, and form important conservation sites. These are extensions of beach into the land and acts as a home for specialized plants and animals and protects the beaches form erosion, control the sea level rise and acts as filter for rainwater and groundwater (Heslenfeld et al 2008). Coastal sand dune flora protects the coastal environment by absorbing energy from wind, tide and wave action. These species played a crucial role in protecting the coast from erosion and flooding, sediments accumulation, sand binding and land building processes. India has an approx $7500 \mathrm{~km}$ coastline along the Arabian Sea on west and bay of Bengal on the east with 2.02 million $\mathrm{Km}^{2}$ exclusive economic zone and 0.13 million $\mathrm{Km}^{2}$ continental shelf with numerous types of plants, lagoons, beaches, estuaries and mangrove swamps. However, these habitats have been severely affected by natural and anthropogenic activities resulting in loss of habitat and dependent flora and fauna. Because it contains a dense population, the coast undergoes environmental modification and deterioration through reclamation, dredging, pollution, industry, and anthropogenic activities (Ingole 2005). Invasion of alien species in coastal sand dune vegetation also threatened the coastal environment (Gallego-Fernandez et al 2019).

The western coastal planes is of $720 \mathrm{Km}$ lie in between the Western Ghats and Arabian Sea and distributed into the coastal districts such as Mumbai, Thane, Mumbai suburbs, Palghar, Raigad, Ratnagiri and Sindhudurg. The Sahyadri mountain range and Western Ghats run parallel to the coast. The $17 \%$ of the total coast is sandy nature, $37 \%$ is rocky and $46 \%$ are mudflats. In $2004,263 \mathrm{~km}$. length of west coastline is affected by erosion, which about $40 \%$ of the Maharashtra coast (Lakshmi et al 2012). The CSD plants act as bio shield against coastal erosion and have many ecological importances. The objective of the current study was to understand the distribution of coastal sand dune plant and to identify the anthropogenic impacts on the CSD flora.

\section{MATERIAL AND METHODS}

Study area: Field visits were conducted at Shiroda $\left(15^{\circ} 45^{\prime} 38.10^{\prime \prime} \mathrm{N} 73^{\circ} 39^{\prime} 49.60^{\prime \prime E}\right)$, Malvan (16 $03^{\circ} 00.73^{\prime \prime} \mathrm{N}$ $\left.73^{\circ} 28^{\prime} 07.93^{\prime \prime E}\right)$ and Achara (16 $\left.11^{\prime} 49.04^{\prime \prime N} 73^{\circ} 26^{\prime} 13.67^{\prime \prime E}\right)$ of Sindhudurg district and Kashid (18 $27^{\prime} 24.21$ "N72 $\left.53^{\prime} 54.68^{\prime \prime E}\right)$ and Revdanda (18 $33^{\prime} 30.45^{\prime \prime N}$ $\left.72^{\circ} 55^{\prime} 13.85^{\prime \prime E}\right)$ from Raigad districts (Fig. 1) during the winter season of month October and November 2020. Generally, the climate of study sites is humid and hot. In winter, the average temperature is in between $22-25^{\circ} \mathrm{C}$ with annual rainfall is 300 to $800 \mathrm{~mm}$.

Sampling: Diversity of plant species were studied by random quadrat method. In each quadrat, sub quadrats of $10 \times 10 \mathrm{~m}$ for trees, sub quadrats of $5 \times 5 \mathrm{~m}$ for shrubs and $2.5 \times 2.5 \mathrm{~m}$ for the herbs. Each quadrat was systematically surveyed by identifying and measuring all trees, shrubs and herbs. 


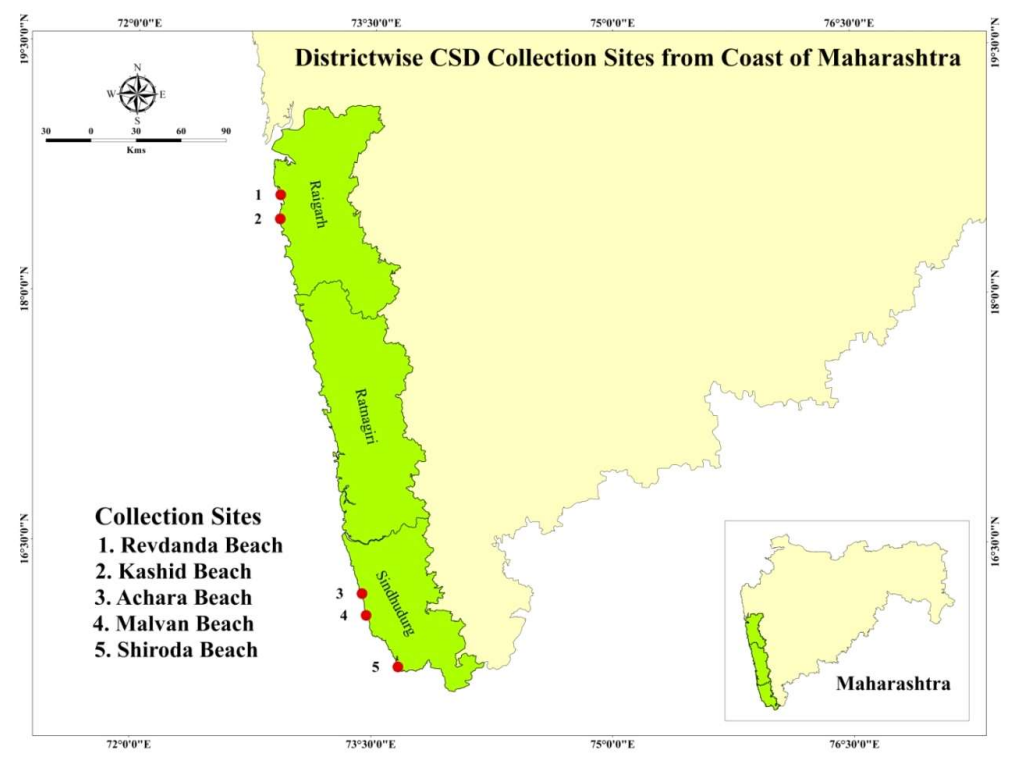

Fig. 1. Location map of the study area

Specimens of individual plant species were collected from each site and were identified using various regional flora and monographs (Cook 1967, Joshi 2011).

\section{RESULTS AND DISCUSSION}

The coastal ecosystem consist 338 species belonging to 69 families of which the west coast consists 267 species and east coast has 163 species indicating more diversity on west coast. Ramarajan and Murugesan (2014) reported 55 species and 26 families from Tamilnadu coast. Silambarasan and Senthilkumaar (2015) reported 39 species belonging to 33 genera and 28 families from Marakkanam Coast, Southeast coast of India. Jana (2016) reported the 82 coastal sand dune species from east Midnapore District, West Bengal, India. Arulmoorthy and Srinivasan (2017) reported 154 species belonging to 108 genera and 41 families from southeast coast of India. Qureshi and Rathod (2020) reported six new algal species from coastal areas of Karwar. During the present work 48 species recorded form different coastal sand dune ecosystems form thewest coast of Maharashtra. Brachiaria distachya, Casuarina equisetifolia, Ipomoea pes-caprae, Sesuvium portulacastrum are the common species found along all the study areas whereas Ammannia baccifera, Calophyllum inophyllum, Pedalium murex are less common and found on only one site. The Shiroda beach shows more diversity (46 species) than the other beaches and Malvan and Kashid beach is less diverse with 23 and 16 species respectively indicating the human intervention. Malvan and Kashid beach are popularly known tourist centres and the CSD plants largely affected by the tourists visiting these places.
The Revdanda and Kashid beach of Raigad district are popularly known tourist centers throughout Maharashtra. These beaches have direct connectivity through private vehicles and public transportation; hence the number of tourists visiting these sites is comparatively more. It was observed that, during the visits to the beaches the tourist pass across the sand dune vegetation and damaging the flora. In Kashid, Revdanda, Malvan and Shiroda, vehicles used for the exploration of beach, which caused more damage to CSD vegetation as compared to human trampling. The other harmful impacts of vehicles includes instability of substrate, disturbing and destruction of vegetation and killing and injuring coastal sand dune associated fauna (Kindermann and Gormally 2010). The tourist use to dump the domestic waste and plastic containers along the sides of beaches that also alters the dunes textures which ultimately leads in the disturbance of CSD flora. Similar observations were recorded for Malvan and Shiroda beach. Comparatively, Achara beach, which is longest but less affected (37 species) may be because of geographical situations, as it is located in the interior and the road and transportation facility is poor hence low trampling activity leads into less destruction of dune vegetation.

\section{CONCLUSIONS}

The current work indicates high number of coastal sand dune flora which strongly affected by tourism industry and other anthropogenic activities. The rate of developments through urbanization is high which in the study area leads into severe destruction of coastal sand dune vegetation. Hence, the effective management strategy for conservation of CSD 
Table 1. Site wise distribution of CSD vegetation of the Maharashtra coast

\begin{tabular}{|c|c|c|c|c|c|c|}
\hline \multirow[t]{3}{*}{ Species name } & \multirow[t]{3}{*}{ Family } & \multicolumn{5}{|c|}{ Locations } \\
\hline & & \multicolumn{3}{|c|}{ Sindhudurg } & \multicolumn{2}{|c|}{ Raigad } \\
\hline & & Sd & $\mathrm{Mn}$ & $\mathrm{Aa}$ & $\mathrm{Kd}$ & $\mathrm{Rd}$ \\
\hline Aeluropus spp. & Poaceae & + & & + & & + \\
\hline Ammannia baccifera L. & Lythraceae & + & & & & \\
\hline Anacardium occidentale L. & Anacardiaceae & + & + & + & & + \\
\hline Barringtonia acutangala (L.) Gaertn. & Lecythidaceae & + & & + & & \\
\hline Borreria articularis (L. f.)F.N.Will. & Rubiaceae & + & & + & & + \\
\hline Brachiaria distachya (L.) Stapf. & Poaceae & + & + & + & + & + \\
\hline Caesalpinia cristata Prowazek & Fabaceae & + & & + & & \\
\hline Calophyllum inophyllum L. & Calophyllaceae & & & + & & \\
\hline Calotropis gigantean (L.) R. Br & Apocynaceae & + & + & + & + & + \\
\hline Senna tora (L.) Roxb & Fabaceae & + & + & + & + & + \\
\hline Casuarina equisetifolia Forst. & Casuarinaceae & + & + & + & + & + \\
\hline Chenopodium album L. & Amaranthaceae & + & & & & + \\
\hline Chromolaena odorata (L.) R. King & Asteraceae & + & & + & & + \\
\hline Clerodendrum inerme (L.) Gaertn & Lamiaceae & + & + & + & & + \\
\hline Cocos nucifera L. & Arecaceae & + & + & + & + & + \\
\hline Colocasia esculenta (L.) Schott & Araceae & + & + & & & + \\
\hline Cyperus rotundus L. & Cyperaceae & + & + & + & + & + \\
\hline Cyperus arenarius Retz. & Cyperaceae & + & & + & & \\
\hline Dactyloctenium aegyptium (L.) Willd. & Poaceae & + & + & + & + & + \\
\hline Hydrophylax maritime L.f. & Rubiaceae & + & & & & \\
\hline Indigofera spp. & Fabaceae & + & & & & \\
\hline Ipomoea pes-caprae (L.) R. Br. & Convolvulaceae & + & + & + & + & + \\
\hline Ixora arborea Roxb. Ex. Sm. & Rubiaceae & + & & + & & + \\
\hline Lantana camaraL. & Verbenaceae & + & + & + & + & + \\
\hline Launaea procumbens (Roxb.) Ramayya \& Rajgopal & Asteraceae & + & & + & & \\
\hline Launea sarmentosa (Willd.) Alston & Asteraceae & + & & + & & + \\
\hline Mollugo disticha (L.) Ser & Molluginaceae & + & & & & \\
\hline Morinda citrifolia L. & Rubiaceae & + & + & + & & \\
\hline Oldenlandia biflora L. & Rubiaceae & + & & & & + \\
\hline Opuntia spp. & Cactaceae & + & & + & + & + \\
\hline Pandanus fascicularis Lam. & Pandanaceae & + & & + & & + \\
\hline Pedalium murex $\mathrm{L}$. & Pedaliaceae & & & & & + \\
\hline Physalis minima $\mathrm{L}$. & Solanaceae & + & + & + & & + \\
\hline Pongamia pinnata (L.)Pierre & Fabaceae & + & + & + & + & + \\
\hline Premna obtusifoliaR.Br. & Lamiaceae & + & & & & \\
\hline Rothia indica (L.) Druce & Fabaceae & + & + & + & & + \\
\hline Sesuvium portulacastrum (L.) L. & Aizoaceae & + & + & + & + & + \\
\hline Sida cordifolia L. & Malvaceae & + & + & + & + & + \\
\hline Spinifex littoreus (Burm.f.) Merr. & Poaceae & + & & + & & \\
\hline Suaeda maritime (L.) Dumort. & Amaranthaceae & + & & & & \\
\hline Tephrosia pupurea (L.) Person. & Fabaceae & + & + & + & + & + \\
\hline Terminalia catappa L. & Combretaceae & + & + & & & \\
\hline Thespesia populnea (L.) Soland. ex Correa & Malvaceae & + & + & + & + & + \\
\hline Tridax procumbens $\mathrm{L}$. & Asteraceae & + & + & + & + & + \\
\hline Vernonia cinerea (L.) Less. & Asteraceae & + & & + & & + \\
\hline Vitex negundo L. & Lamiaceae & + & & + & & + \\
\hline Waltheria indica $\mathrm{L}$. & Malvaceae & + & + & + & & + \\
\hline Ziziphus jujube Miller & Rhamnaceae & + & & + & & + \\
\hline Total & 27 & 46 & 23 & 37 & 16 & 35 \\
\hline
\end{tabular}

Sd-Shiroda, Mn-Malvan, Aa-Achara, Kd-Kashid, Rd-Revdanda 
Table 2. Morphological observations of the study site beaches

\begin{tabular}{|c|c|c|c|c|c|c|c|c|}
\hline $\begin{array}{l}\text { Name of } \\
\text { study sites }\end{array}$ & $\begin{array}{l}\text { Length } \\
(\mathrm{M})^{\star}\end{array}$ & $\begin{array}{l}\text { Type of } \\
\text { beach }\end{array}$ & Connectivity & $\begin{array}{l}\text { Tourist } \\
\text { attraction }\end{array}$ & $\begin{array}{l}\text { Environmental } \\
\text { Characteristics }\end{array}$ & Pollution & Beach services & Dune $^{* *}$ type \\
\hline $\begin{array}{l}\text { Revdanda } \\
\text { (Raigad) }\end{array}$ & 4350 & $\begin{array}{l}\text { Rural- } \\
\text { Urbanized }\end{array}$ & $\begin{array}{l}\text { Private vehicle } \\
\text { Public } \\
\text { Transportation } \\
\text { Easy Access by } \\
\text { walking and } \\
\text { bike }\end{array}$ & $\begin{array}{l}\text { Beach } \\
\text { camping } \\
\text { Sun Bathing } \\
\text { Fishing }\end{array}$ & $\begin{array}{l}\text { Soft waves. } \\
\text { Baby dune } \\
\text { presence } \\
\text { Casurina } \\
\text { vegetation. } \\
\text { Mangroves }\end{array}$ & $\begin{array}{l}\text { Litter } \\
\text { Domestic } \\
\text { sewage } \\
\text { Fishing waste }\end{array}$ & $\begin{array}{l}\text { Restaurants } \\
\text { Accommodation } \\
\text { Parking space }\end{array}$ & $\begin{array}{l}\text { Incipient } \\
\text { dune }\end{array}$ \\
\hline $\begin{array}{l}\text { Kashid } \\
\text { (Raigad) }\end{array}$ & 3319 & $\begin{array}{l}\text { Rural- } \\
\text { Tourism } \\
\text { center }\end{array}$ & $\begin{array}{l}\text { Private vehicle } \\
\text { Easy Access by } \\
\text { walking and } \\
\text { bike }\end{array}$ & $\begin{array}{l}\text { Beach } \\
\text { camping } \\
\text { Beach Sport } \\
\text { Horse Ride }\end{array}$ & $\begin{array}{l}\text { Strong waves. } \\
\text { Signs of tourism } \\
\text { disturbance. } \\
\text { Casurina } \\
\text { vegetation. } \\
\text { Coconut } \\
\text { farmingalongside } \\
\text { beach }\end{array}$ & $\begin{array}{l}\text { Litter } \\
\text { Domestic } \\
\text { sewage by local } \\
\text { restaurant. } \\
\text { Plastic waste }\end{array}$ & $\begin{array}{l}\text { Restaurants } \\
\text { Accommodation } \\
\text { Parking space } \\
\text { Sport gear } \\
\text { Lifeguard } \\
\text { Changing rooms. }\end{array}$ & $\begin{array}{l}\text { Incipient } \\
\text { dune }\end{array}$ \\
\hline $\begin{array}{l}\text { Achara } \\
\text { (Sindhudurg) }\end{array}$ & 12880 & Rural & $\begin{array}{l}\text { Private vehicle } \\
\text { Easy Access by } \\
\text { walking and } \\
\text { bike }\end{array}$ & $\begin{array}{l}\text { Small scale } \\
\text { Beach } \\
\text { tourism }\end{array}$ & $\begin{array}{l}\text { Soft waves. } \\
\text { Sign of coastal } \\
\text { erosion } \\
\text { Spinifix vegetation. }\end{array}$ & Plastic waste & $\begin{array}{l}\text { Small } \\
\text { Restaurants } \\
\text { Parking space }\end{array}$ & $\begin{array}{l}\text { Incipient } \\
\text { dune }\end{array}$ \\
\hline $\begin{array}{l}\text { Malvan } \\
\text { (Sindhudurg) } \\
\text { Commercially } \\
\text { active beach }\end{array}$ & 1506 & $\begin{array}{l}\text { Urban } \\
\text { Tourism } \\
\text { center }\end{array}$ & $\begin{array}{l}\text { Private vehicle } \\
\text { Public } \\
\text { Transportation } \\
\text { Easy Access by } \\
\text { walking and } \\
\text { bike }\end{array}$ & $\begin{array}{l}\text { Tourist } \\
\text { hotspot. } \\
\text { Ferry service } \\
\text { to } \\
\text { Sindhudurg } \\
\text { fort. } \\
\text { Scuba diving. } \\
\text { Snorkeling \& } \\
\text { Beach safari } \\
\text { Beach } \\
\text { Tourism. }\end{array}$ & $\begin{array}{l}\text { Soft waves. } \\
\text { Signs of tourism } \\
\text { disturbance. } \\
\text { Anthropogenic } \\
\text { activities. } \\
\text { Fishing } \\
\text { disturbance. } \\
\text { Less vegetation. }\end{array}$ & $\begin{array}{l}\text { Litter,Domestic } \\
\text { sewage and } \\
\text { waste by local } \\
\text { restaurant and } \\
\text { residents } \\
\text { Open sanitation } \\
\text { on beach.Plastic } \\
\text { waste }\end{array}$ & $\begin{array}{l}\text { Restaurants \& } \\
\text { beach resorts. } \\
\text { Parking space } \\
\text { Accommodation } \\
\text { Water sport gears } \\
\text { Local guide } \\
\text { Ferry services. } \\
\text { Lifeguard }\end{array}$ & $\begin{array}{l}\text { Incipient } \\
\text { dune }\end{array}$ \\
\hline $\begin{array}{l}\text { Shiroda } \\
\text { (Sindhudurg) }\end{array}$ & 4464 & $\begin{array}{l}\text { Rural } \\
\text { Tourism } \\
\text { center }\end{array}$ & $\begin{array}{l}\text { Private vehicle } \\
\text { Easy Access by } \\
\text { walking and } \\
\text { bike }\end{array}$ & $\begin{array}{l}\text { Beach } \\
\text { camping } \\
\text { Sun Bathing } \\
\text { Foreign } \\
\text { tourist } \\
\text { attraction. } \\
\text { Water sport. }\end{array}$ & $\begin{array}{l}\text { Strong waves. } \\
\text { Signs of tourism } \\
\text { disturbance. } \\
\text { Casurina \& Spinifix } \\
\text { vegetation. } \\
\text { Anthropogenic } \\
\text { activities. } \\
\text { Large CSD area. }\end{array}$ & $\begin{array}{l}\text { Litter } \\
\text { Domestic } \\
\text { sewage and } \\
\text { waste by local } \\
\text { restaurant and } \\
\text { residents. } \\
\text { Plastic waste }\end{array}$ & $\begin{array}{l}\text { Restaurants \& } \\
\text { beach resorts. } \\
\text { Bars } \\
\text { Parking space } \\
\text { Accommodation } \\
\text { Water sport gears }\end{array}$ & $\begin{array}{l}\text { Incipient } \\
\text { dune \& } \\
\text { Foredune, } \\
\text { blowouts }\end{array}$ \\
\hline
\end{tabular}

*Maharashtra Maritime Board, Government of Maharashtra Report, 2017

** Classification based on Short \& Hasp (1982)

through strong implementation of laws, modification of coastal conservation policies and appropriate plantation program is the need of time. It is very important to conserve and protect the coastal sand dune vegetation for coastal protection and ecosystem management.

\section{ACKNOWLEDGEMENT}

Authors are grateful to the Chhatrapati Shahu Maharaj Research, Training and Human Development Institute (SARTHI), Pune for providing research fellowship.

\section{REFERENCES}

Arulmoorthy MP and Srinivasan M 2017. Coastal sand dune floral diversity in Cuddalore coastal areas, southeast coast of India. Asian Journal of Plant Science and Research 7(3): 60-64.

Cooke T 1967. The flora of the presidency of Bombay, Botanical Survey of India, Culcutta, India.

Gallego Fernández JB, Martinez ML, Garcia-Franco JG and Zunzunegui M 2019. The impact on plant communities of an invasive alien herb, Oenothera drummondii, varies along the beach-coastal dune gradient. Flora-Morphology Distribution Functional Ecology of Plants 260(3): 151466

Heslenfeld P, Jungerius PD and Klijn JA 2004. European coastal dunes: ecological values, threats, opportunities and policy development, p 335-351 In: Martínez ML, Psuty NP (Eds.). Coastal Dunes. Ecological Studies, Vol. 171. Springer, Berlin, Heidelberg.

Jana B 2016. Study on sand dune vegetation in east Midnapore District, West Bengal, India. International Journal for Scientific Research \& Development 4(5): 1662-1666.

Joshi AJ 2011. Monograph on Indian Halophytes, p 140. BhavnagarUniversity, Bhavnagar.

Ingole BS 2005. Indian Ocean coasts, coastal ecology p. 546-554. In: Schwartz ML (Ed.) Encyclopedia of Coastal Science. Springer, Dordrecht.

Kindermann G, and Gormally MJ 2010. Vehicle damage caused by recreational use of coastal dune systems in a Special Area of Conservation (SAC) on the west coast of Ireland. Journal of Coastal Conservation 14(3): 173-188.

Lakshmi A, Schiavina A, Banerjee P, Reddy A, Mandeen S, Rodriguez S and Apte D 2012. The Challenged Coast of India, A report prepared by PondyCAN in collaboration with BNHS and TISS. p136.

Maharashtra Maritime Board, Government of Maharashtra Report, 2017. Maharashtra 
Shoreline Management Plan 2017. Individual Beach Assessments: Sindhudurg District, Prepared by Sanctuary Beach Pvt Ltd Singapore, p 229.

Maharashtra Maritime Board, Government of Maharashtra Report, 2017. Maharashtra Shoreline Management Plan 2017 Individual Beach Assessments: Raigad District, Prepared by Sanctuary Beach Pvt Ltd Singapore, p 144.

Qureshi G and Rathod JL 2020. Ecological future scenario 2020 of marine macro algal flora of Karwar coastal area, arabian sea,

Received 22 October, 2021; Accepted 03 January, 2022
India. Indian Journal of Ecology 47(3): 759-763.

Ramarajan S and Murugesan AG 2014. Plant diversity on coastal sand dune flora, Tirunelveli district, Tamilnadu. Indian Journal of Plant Sciences 3(2): 42-48

Silambarasan K and Senthilkumaar P 2015. Distribution and Diversity of Coastal Sand Dunes (CSD) of Marakkanam Coastal Belts, Southeast Coast of India. Species 12(35): 101-105.

Short AD and Hesp PA 1982. Wave, beach and dune interactions in southeastern. Australia. Marine Geology 48(3-4): 259-284. 